\title{
Ecocentrism and Its Alternatives Within the Worldview Paradigm
}

\author{
Valeriy Nekhamkin \\ Bauman Moscow State Technical University \\ 5/1 2nd Baumanskaya Str. \\ Moscow, Russia 105005 \\ E-mail: nechamkin@ @rambler.ru
}

\author{
Galina Chernogortseva \\ Bauman Moscow State Technical University \\ $5 / 1$ 2nd Baumanskaya Str. \\ Moscow, Russia 105005 \\ E-mail: irbiscotta@mail.ru
}

\author{
Nikita Kishkin \\ Bauman Moscow State Technical University \\ 5/1 2nd Baumanskaya Street \\ Moscow, Russia 105005 \\ I.M. Sechenov First Moscow State Medical University of \\ the Ministry of Health of the Russian Federation \\ 8-2, Trubetskaya Str. \\ Moscow, Russia 119991 \\ E-mail: kishkin.nikita@rambler.ru
}

\begin{abstract}
The article dwells upon the three systems of natural and scientific worldviews: anthropocentrism, biocentrism, ecocentrism. It states that each system has certain basic theses, plays the role of an aggregate of behavioral attitudes and theoretical theses. Their hierarchy is being revealed. The utopic nature of certain attitudes is shown by the authors. The article shows the interconnection between anthropocentrism, biocentrism, and ecocentrism and the respective types of knowledge: classical science, non-classical science, and post-non-classical science. It has been concluded that ecocentrism offers the best way of nature-society interaction. However, this worldview type needs further development at both natural and scientific knowledge levels.
\end{abstract}

Keywords-anthropocentrism; biocentrism; ecocentrism; worldview; philosophy; science

\section{INTRODUCTION}

The Worldview (being a meaningful system of a person's view of the world as a whole and their place in it) plays an important role in people's lives; it forms their meaningful view of the real world. One of the most important questions here is the development of proper attitude of people to the interaction within the "society-nature" and "individualenvironment" systems. In order to deal with it the existing points of view on this matter and the respective mindsets should be revealed [1].

The criteria for distinction between the concepts considered are basic forms of interaction within the "humannature" system which are based either on the role of one of the subjects in the system being made absolute, or on both subjects being recognized as principally equal and evolutionizing together thus being the main factor of life preservation on Earth. Basing ourselves on this approach we can distinguish between the following three alternating concepts in people's worldviews: anthropocentrism (the influence of human and society on nature is prioritized), biocentrism (is based on the thesis that human is dependent on the physical and especially biological world and should by no means try to adjust them in accordance with their egoistic and pragmatic needs), ecocentrism (has the objective of eliminating extremities like that and proving the coevolution and co-existence of natural and social worlds to be essential and possible). We shall consider every viewpoint as a special model, revealing the background factors they are caused by, the basic theses, the possible conclusions.

\section{ANTHROPOCENTRISM}

Anthropocentrism is a worldview which presupposes that people, and society generated by their interaction, are the main elements in the system "human-nature". The environmental values should be dependent on the society, its establishment, since individuals are practical, sensible creatures that transform and adjust the world directed by their thinking. The nature, however, is seen as being of spontaneous, irrational origin; the nature should be "tamed" by homo sapience, and put at the sense's "service". This viewpoint can be found back in the words of ancient philosopher Protagoras: "Of all things the measure is Man, of the things that are, that they are, and of the things that are not, that they are not" [2, p.316].Centuries later the same position would be expressed in Marxism as well. In "Theses on Feuerbach" Karl Marx would argue that: "Philosophers (before Marxism - author's note) have hitherto only 
interpreted the world in various ways; the point is to change it" [3, p.266].

Classical science also played an essential role in the establishment of Anthropocentrism. The worldview based on it required the real life to be modified on the basis of laws made by scientists [4].

The authors see it possible to distinguish between two stable lines within Anthropocentrism, namely religious and secular. The former (which manifested itself to a great extent in Christianity) originates from a Bible's thesis (Genesis) about the creation of man "after God's image, after God's likeness" (Genesis I, 26), i.e. the man appeared to be the closest to the Creator and due to this fact seemingly got the right to modify the nature without being controlled, to limitlessly dominate over the biological world. This standpoint to some extent lost its topicality in the Middle Ages (because of the governing opinion of a man's insignificance before God), but it reemerged in Early Modern Period on the basis of human intelligence (based on science) being regarded as almighty [5].

The latter is based on the idea that the man is the paragon of natural evolution. The man possesses intelligence. The man put at service a great means of modifying reality, the science; the man created machinery. People can and should make plans of modifying nature being governed by intelligence. This is where anthropocentric attitudes in scientific knowledge and philosophy come from. Pierre Teilhard de Chardin makes a direct appeal: "Man, the centre of perspective, is [at the same time the centre of construction of the universe]. And by expediency no less than by necessity[author's italics], all science must be referred back to him" $[6, p .38]$.The anthropocentric reduction of the kind manifested itself not only in natural science where the following attitude of Russian-soviet selectionist I.V. Michurinbecame widespread: "We cannot wait for the nature's mercy. Our task is to take the mercy from it". Its influence can be seen in humanitarian sciences as well. Ernst Bernheimsaw "the facts of people's development in their activities as social creatures" as the object of the historical science[7, p.16]. According to Vladimir Guerrier Philosophy of History (which theoretically summarizes the knowledge obtained by historians) also studies the specific synthesis by which "a thinking person grasps the aggregate of the mankind history, its flow and purpose" $[8, p .1]$. The reader can see the anthropocentric tendency in other humanitarian sciences and philosophical concepts of the first half of the 20th century as well.

However, in the second half of the 20th century anthropocentrism found itself compromised by a number of factors. Firstly, the two world wars (1914-1918, 1939-1945) showed that "of all things the measure" man is, but not positive enough if the man allowed the growth of antihumanism, mainstreamed technologies which took million people's lives. Secondly, science gave not only the means of facilitating people's lives but also destroying the whole mankind (nuclear weapons). In 1930-1940s "scientists" from Japan (Detachment 731), from Nazi Germany conducted brutal experiments over people without their consent. Thus, the manifestation of intellect as science striving for truth by all possible means required selfrestriction. Thirdly, science and its achievements led in the 20th century to a drastic growth of production. The other side of the process is manifested in ecological problems and their aggravation. Here the scientists were powerless since "one-sidedness" and consumer character of their attitude to nature did not allow finding a way out of the situation. Appeals to strengthen people's regulatory function in relation to the biological space around society (for example the "human qualities" model by Aurelio Peccei) were not a solution of the problem. Therefore, biocentrism as a worldview attitude different in essence had to come forth.

\section{BIOCENTRISM}

Biocentrism is a worldview attitude opposite to anthropocentrism. Its supporters try to shift the vector of interaction in the "human-nature" system from the former to the latter, claiming the latter to be dominating. The scientific basis of biocentrism is non-classical science which formed in the second half of the 20th century and which came away from fixed cause-and-effect dependence recorded by classical science to come to the ideas about non-linearity, non-equilibrium, fluctuation of the surrounding world [9].

Biocentrism can have different manifestation. An interesting fact is that in European tradition it is of theoretical character mainly, in oriental tradition it has the character of practical (ethical) ideas which people should follow. In Europe the following periods of the development of this attitude should be mentioned. The first one: the definition of man as a special living creature ("a two-legged animal without feathers", Plato; "a political animal", Aristotle, "a symbolic animal', Ernst Cassirer). The second one: appeal to come "back to nature" made by Jean-Jacques Rousseau in the 18th century which manifested itself later in the "ecological imperative" of Nikita Moiseev (who insisted upon a person's taking into account the "nature's interests"), and in the concise "ethics of life" of Albert Schweitzer. The peculiar result of the establishment of the given viewpoint was the concept of biologist Mikhail Gusev who stressed the necessity of transition from "anthropocentrism to biocentrism" at the end of the 20th century. The latter, though, was of an anthropocentric character since it had the requirement for people not to consume animals which "had gleams of consciousness" [10, p.75] and did not prevent any experiments over animals conducted by scientists.

In the Orient biocentrism had features not only similar to the European biocentrism (for example, Arabic philosopher of the 8-9th centuries Al-Farabi, or Alpharabius, just like Plato defined the man as a "laughing animal") but also different from it. Here the practical focus of the concept came to the forth. Thus, in Ancient India (in the 6-5th centuries BC Jainism appeared, a school of thought and religion which was based on the "ahimsā" principle in accordance with which a living creature must by no means be killed or harmed). That is why Jains drink water through a sieve in order not to kill insects, and follow the canons of vegetarianism. 
Synthesis of theoretical and practical lines of biocentrism gave its general theses which can be formulated by the authors as follows. "Firstly, the man lives in a natural environment, is dependent on it. Secondly, the physical and especially the biological worlds are not people's "absolutely owned patrimony", they should adjust their needs in accordance with the nature's needs). Thirdly, science must develop technologies which are aimed at preserving the natural resources, not at their destruction. In the fourth place, if a person's interests were of a primary character in classical scientific thought, in non-classical science an opposite idea of nature dominating in this system (as biota) appears [11].

Position of the kind was a step up as compared with anthropocentrism. Although it contained fundamentally utopian lines. Today's mankind is not able to fully give up on "violating" the biological world, using its resources (including consumption of living creatures as food) to survive (including scientific experiments conducted over animals). Otherwise, it is doomed to peril or drastically decrease from today's 7.5 billion to $700-800$ million people.

\section{ECOCENTRISM}

Ecocentrism is a worldview attitude in accordance with which the establishment of natural and social worlds should be a co-evolutionary process, with the interests (needs) of the parties taken into account. It is opposite to both anthropocentrism and biocentrism since it does not insist upon one of the elements dominating in the "human-nature" system.

Ecocentrism was given rise to by neo-non-classical science (post-non-classical science) which is able to perform computer simulation (modelling) of certain natural processes (thereby comprehending their complexity), which bases itself on systemic approach and synergy as its methodology, which makes no attempts of seeing nothing but harsh laws working in our reality. [12].

The main theses of ecocentrism, according to the authors, can be as follows. "Firstly, it is co-evolution in the "humannature" system (mutual balanced existence and development) that is most valued. Secondly, since it is only human who is the carrier of intellect (higher animals possess "so far" only the rudiments of intellectual activity) only human can be self-conscious and able to control their activity. In the third place, ecocentrism presupposes the creation of a "fraternal" hierarchical worldview of a certain kind in which human performs their activity basing themselves on self-limited scientific intellect. In the fourth place, the purpose of interaction in the "human-nature" system is, on the one hand, satisfaction of a man's needs, and on the other hand, it is preservation of physical and biological worlds as valuable the way they are. In the fifths place, it is the choice of "ecological imperative" as the behavioral principle, fundamentally different from that of biocentrists and broader in its concept, whose norm is as follows: "the only right and allowed thing is the one that does not disturb the balance existing in nature" [13, p.13].The latter serves to some extent as the manifestation of bioethical principle of "nonmaleficence" in relation to natural systems" [11].
What are the advantages of ecocentrism as a worldview system over its predecessors? Firstly, it does not oppose nature (physical and biological) and social world, but insists upon the development of balance in their relations. Secondly, it bases itself on the youngest form of scientific knowledge, namely post-non-classical science (for anthropocentrism the basis is classical science, and for biocentrism it is nonclassical science), which allows revealing nonlinear complex interdependencies between nature and society. In the third place, it works perfectly well using the methodology of interdisciplinary lines of scientific cognition (synergy, systemic approach). In the fourth place, it allows justifying the necessity of developing synthetic approaches to studying nature and society (sociobiology, "socio-natural history" by Eduard Kulpin [14] and other). In the fifths place, it gives an impulse for international development of programs in which the principles of co-evolution of nature and society are realized [15]. In the sixths place, it opens up the way to creation of technologies which lead to the balance of nature and society rather than to struggle, opposition, and its permanent actualization in the mind of society (which is characteristic of anthropocentrism).

\section{CONCLUSION}

The analysis carried out in the present paper allows making the following conclusions. Firstly, anthropocentrism, biocentrism, ecocentrism judging by their worldview attitudes are concepts not only opposite but also completing each other. Indeed, without the possibility of establishing a consensus between society and natural environment the life on Earth may simply seize to exist. That is why each position both demonstrates its own extremities, and shows the "limits" beyond which a man's actions become devastating for the ecosystems as a whole.

Secondly, in the "society-nature" interaction it is important for people to see not only the options implemented in practice but also the other ones, which have been missed by different social subjects. This fact requires the development of special methodology for a detailed analysis, which one of the authors worked at [16 - 19].However, there is still much to do along this line, making counter-factual modelling of the past work for studying a specific object as interrelations in the "human (society)-nature" system. For example, Russian historiosopher Veniamin Khvostov is right when he claims: "the history of the world would have been totally different if the position of land and sea had been different" [20, p.218].Let us remember: at the moment their proportion is $29,2 \%$ to $70,8 \%$ respectively, but it underwent changes in the course of evolution and it is this configuration that gave birth to today's society. What if it had not been that way? What would the mankind be like in this case? Would it reach the technical heights, or would people live like it is shown in a well-known Hollywood film "Waterworld", trying to survive in the limitless water area? These are not idle questions, they require an answer today since tomorrow they may require concrete management decisions on the reasons for climate change at the end of the 20th and the beginning of the 21 st centuries. 
In the third place, out the three worldview attitudes considered the most preferable would be ecocentrism according to the authors. It a) insists upon the co-evolution of nature and society (human); b) does not oppose them; c) sets the directions of their balanced interaction.

\section{REFERENCES}

[1] Gubanov N.I., Gubanov N.N. The role of mentality in the development of society: sociocultural hypothesis // Vestnikslavyanskikh kultur-bulletin of slavic cultures-scientific and informational journal. 2017. Vol. 43. № 1. P. 38-51.

[2] Anthology of World Philosophy. 4 Vol. Vol. 1. Pt. 1. M.,Misl. 1969.

[3] Marx K., Engels F. Essays. Vol. 42. M., Politizdat. 1955.

[4] Lazarev F.V., Lebedev S.A. The Philosophical Reflex: Essence, Form, Types // Voprosyfilosofii. 2016. № 6. P. 15-28.

[5] Nesterenko A.N. Bishop Albert // Voprosyistorii. 2015. № 3. P. 50-68.

[6] Chardin P.T. Phenomenon of Man. M., Nauka. 1987.

[7] Bernheim E. Introduction into Historical Science. SpB, VestnikZnanya (V.V. Bitner). 1908.

[8] Guerrier V. Philosophy of History. From Augustin to Hegel. M., Tovarischestvo "Petchatnia S.P. Yakovleva". 1915.

[9] Lebedev S.A. The Structure of Scientific Rationality // Voprosyfilosofii. 2017. № 5. P. 66-79.

[10] Gusev M.V. From Anthropocentrism to Biocentrism // Moscow University Bulletin. Series 7. Philosophy. 1992. No. 5. P.71-76.

[11] Kishkin N.V., Nekhamkin V.A. The Notion of Ecocentrism: Scientific Philosophical Content // GumanitarniiVestnik. 2017. No.8 (58). P.4.DOI:10.18698/2306-8477-2017-8-459.

[12] Komissarov I; Nekhamkin V. The Models of Historical Cognition: Current Status and Prospects of Development // IstoriyaElektronnyinauchno-obrazovatelnyuzhurnal. 2017. Vol. 8. Issue 2. DOI: 10.18254/S0001779-5-1.

[13] Derebo S.V., Yasvin V.A. Ecological Pedagogy and Psychology. Rostov-on-Don, Publishing House "Phoenix". 1996.

[14] Kulpin-Gubaidulin E.S. Socionatural History: from method to theory, from theory to practice. Volgograd. PublishingHouse "Utchitel". 2014.

[15] Suzdaleva T.R. Migratory processes in the context of geopolitics // VestnikTomskogogosudarstvennogouniversiteta-Filosofiyasotsiologiya-politologiya-Tomsk state university journal of philosophy sociology and political science. 2016. № 3 (36). P. 237244. DOI: $10.17223 / 1998863 X / 35 / 25$.

[16] Nekhamkin V.A. Counterfactual Historical Modelling of K.Clausewitz: Theoretical Methodological Aspect // Voprosyfilosofii. 2006. No.6. P.105-115.

[17] Nekhamkin V.A. Counterfactual Historical Investigations // Historical Psychology and Sociology of History. 2011. Vol.4. No.1. P.102-120.

[18] Nekhamkin V.A. Scenarios of might-have-been history: pros and cons //Herald of Russian Academy of Sciences. 2009. Vol. 79. № 6. P. 580-586.

[19] Nekhamkin V.A. A counterfactual challenge of the past: Ways of negotiation // Herald of the Russian Academy of Sciences. 2017. Vol 87. Issue 2. P. 191-198.

[20] Khvostov V.M. Theory of Historical Process. Essays on Philosophy and Methodology of History. Course of Lectures. M., URSS, KomKniga. 2006. 